\title{
Curcuminoid submicron particle ameliorates cognitive deficits and decreases amyloid pathology in Alzheimer's disease mouse model
}

\author{
Yi-Heng Tai ${ }^{1, *}$, Yu-Yi Lin ${ }^{1, *}$, Kai-Chen Wang ${ }^{2,}{ }^{*}$, Chao-Lin Chang ${ }^{3}$, Ru-Yin Chen ${ }^{3}$, \\ Chia-Chu $\mathrm{Wu}^{3}$ and Irene $\mathrm{H}$. Cheng ${ }^{1,4}$ \\ ${ }^{1}$ Institute of Brain Science, National Yang-Ming University, Taipei, Taiwan \\ ${ }^{2}$ Department of Neurology, Cheng-Hsin General Hospital, Taipei, Taiwan \\ ${ }^{3}$ Food Industry Research and Development Institute, Hsinchu, Taiwan \\ ${ }^{4}$ Brain Research Center, National Yang-Ming University, Taipei, Taiwan \\ "These authors have contributed equally to this work \\ Correspondence to: Irene H. Cheng, email: hjcheng@ym.edu.tw \\ Keywords: Alzheimer's disease; curcuminoid submicron particle; APP transgenic mouse; amyloid; curcumin \\ Received: August 29, $2017 \quad$ Accepted: January 25, $2018 \quad$ Published: January 31, 2018 \\ Copyright: Tai et al. This is an open-access article distributed under the terms of the Creative Commons Attribution License 3.0 \\ (CC BY 3.0), which permits unrestricted use, distribution, and reproduction in any medium, provided the original author and source \\ are credited.
}

\section{ABSTRACT}

\begin{abstract}
Alzheimer's disease (AD) is the most prevalent neurodegenerative disorder and is triggered via abnormal accumulation of amyloid- $\beta$ peptide $(A \beta)$. Aggregated $A \beta$ is responsible for disrupting calcium homeostasis, inducing neuroinflammation, and promoting neurodegeneration. In this study, we generated curcuminoid submicron particle (CSP), which reduce the average size to $\sim 60 \mathrm{~nm}$ in diameter. CSP had elevated the bioavailability in vivo and better neuroprotective effect against oligomeric $A \beta$ than un-nanosized curcuminoids in vitro. Two months of CSP consumption reversed spatial memory deficits and the loss of a calcium binding protein calbindin- $D_{28 \mathrm{k}}$ in the hippocampus of AD mouse model. In addition, CSP consumption lowered amyloid plaques and astrogliosis in vivo and enhanced microglial $A \beta$ phagocytosis in vitro, implying that the beneficial effects of CSP also mediated via modulating neuroinflammation and enhancing amyloid clearance. Taken together, our study demonstrated the protective effects of CSP toward ameliorating the memory impairment and pathological deficits in AD mouse model.
\end{abstract}

\section{INTRODUCTION}

Alzheimer's disease (AD) is the most common form of dementia affecting more than 46 million patients worldwide. Abnormal accumulation of extracellular amyloid- $\beta$ peptide $(A \beta)$ into amyloid plaques in the brain is one of the pathological hallmarks of $\mathrm{AD}$. $\mathrm{A} \beta$ is produced through the sequential proteolysis processing of amyloid precursor protein (APP) by $\beta$ - and $\gamma$-secretases. Among different length of $A \beta, A \beta 40$ is the most abundant species and accounts for $90 \%$ of total $\mathrm{A} \beta$ in the brain. However, $\mathrm{A} \beta 42$ is more aggregation-prone and more neurotoxic than other $\mathrm{A} \beta$ species, and thus play the major pathogenic role in $\mathrm{AD}[1,2]$. Overexpression of $\mathrm{A} \beta$ deteriorates the cognitive function; on the contrary, reduced levels of $A \beta$ are often associated with alleviating the cognitive deficits [3]. Impaired clearance of $A \beta$ is one of the major the factors that result in the cognitive dysfunction in sporadic AD patients [4].

Neuroinflammation triggered by the activation of astrocyte and microglia plays a central role in the pathogenesis of $\mathrm{AD}[5,6]$. Astrocytes are a key regulator of neuroinflammation and important for maintaining neuronal functions. Extensive proliferation of astrocytes induced by $\mathrm{A} \beta$ with a reactive phenotype and abnormal regulation leads to cognitive decline in $\mathrm{AD}$ [7]. Microglia, 
the primary immune cells of the brain, play an important role in maintaining neuronal function and protecting the brain from insults. The activation of microglia has both beneficial and detrimental roles in AD. Activated microglia could be classified into two phenotypes: M1 inflammatory microglia and M2 anti-inflammatory microglia [8]. M1 phenotype microglia can be triggered by $\mathrm{A} \beta$ to produce pro-inflammatory cytokines, which drive downstream cytokine storm to induce cytotoxicity [9]. In contrast, M2 phenotype microglia play protective roles against $\mathrm{A} \beta$-induced damages [10-12].

Curcuminoid is a group of natural polyphenol consisted of diarylheptanoid compounds derived from the rhizomes of Curcuma Longa, such as curcumin and demethoxycurcumin. Epidemiological studies suggested that curcuminoid consumption is highly associated with the lower prevalence of AD in India $[13,14]$. In addition, curcumin could inhibit neuroinflammation and reduce amyloid deposition in AD mouse model [15-17]. However, curcumin intake failed to reduce the amyloid levels in AD patients in the clinical trial [18]. The major limitation using curcuminoid as a treatment/protective agent is its low bioavailability, which is caused by its poor water solubility and low absorption rate in the gastrointestinal tract $[19,20]$. Several approaches have been applied to overcome this problem, including structural modifications, pharmaceutical adjuvants, liposomes, and nanoparticles $[19,21,22]$. However, none of them significantly improve the spatial memory deficits in AD mouse model. Nanoparticle technology has emerged as a promising access to enhance bioavailability of lipophilic molecules such as curcumin [22-24]. The advantage of this nanoparticle technology is to reduce the average size of curcuminoid without structure modification that may alter curcuminoid nature properties.
In this study, we produced curcuminoid submicron particle (CSP) to average size around $60 \mathrm{~nm}$ in diameter and investigate the neuroprotective effects of CSP in vitro and in vivo. We found that CSP had higher bioavailability, improved spatial learning and memory, and reduced amyloid pathology in APP transgenic mouse. Furthermore, CSP could inhibit neuroinflammation and promote phagocytosis to clear A $\beta$. Our study suggested a potential use of CSP for future AD intervention.

\section{RESULTS}

\section{CSP had better protective effect against oligomeric $\mathrm{A} \beta$ in vitro}

To compare the neuroprotective effect, oligomeric $\mathrm{A} \beta$ (oA $\beta$ ) treated SH-SY5Y human neuroblastoma cells were co-incubated with $5 \mu \mathrm{M}$ curcuminoid submicron particle (CSP) or un-nanosized curcuminoids (C) for 48 hours, and their viability was determined by MTT assay. The survival rate in oA $\beta$ treated cells was significantly decreased compared with non-treated cells. Coincubation with 0.044 and $0.22 \mu \mathrm{M}$ CSP or un-nanosized curcuminoids significantly reversed oA $\beta$-induced neuronal death. In particular, $0.22 \mu \mathrm{M}$ CSP treated cells had significantly higher survival rate than un-nanosized curcuminoids under A $\beta$ stress (Figure 1). Because CSP had better neuroprotective effect against $\mathrm{A} \beta$ in vitro, we further tested the potential use of it to prevent neurodegeneration in vivo.

\section{Genotoxicity and biosafety of CSP}

Before applying to $\mathrm{AD}$ animal model, we first examined the biosafety of CSP after oral consumption.

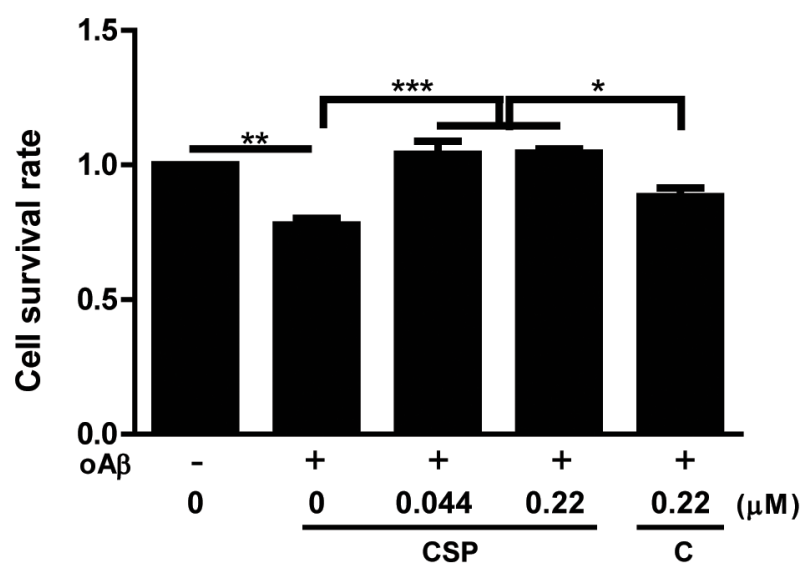

Figure 1: CSP had better protective effect against oligomeric A $\beta$ (oA $\beta$ ) than un-nanosized curcuminoid in vitro. SHSY5Y cells were pre-treated with $0,0.044$ or $0.22 \mu \mathrm{M}$ curcuminoid submicron particle (CSP) or $0.22 \mu \mathrm{M}$ un-nanosized curcuminoid (C) for 4 hours and then co-treated with $5 \mu \mathrm{M}$ oA $\beta$ for 48 hours. The cell survival rate was determined by MTT assay in 3 independent experiments (N=8 per experiment). Results were analyzed by one-way ANOVA. ${ }^{* * *}, \mathrm{P}<0.001 ;{ }^{* *}, \mathrm{P}<0.01 ;{ }^{*}, \mathrm{P}<0.05$. The survival rate of SH-SY5Y cells treated with vesicle control was set as 1 . 
The acute genotoxicity of CSP was determined using micronucleus assay. ICR male mice were administrated with $0.03,0.3$, and $3 \mathrm{~g} / \mathrm{kg}$ of CSP, vesicle (negative control), or cyclophosphamide (positive control). The percentage of micronucleated erythrocytes in plasma was used as an indicator of chemical-induced genotoxicity. The percentage of micronucleated erythrocytes in CSP treated groups had no significant difference in comparison with vesicle control group, suggesting that CSP did not induce significant genomic instability and toxicity (Supplementary Table 1).

The biosafety of CSP was determined by administration of $0,0.1,0.5$, and $1.0 \mathrm{~g} / \mathrm{kg} /$ day of CSP to male and female Sprague-Dawley (SD) rats for continuous 28 days (short-term) and 90 days (long-term). All groups had no apparent adverse effects and recorded death (Supplementary Table 2). Furthermore, there were no significant changes in average body weight (Figure 2A-2B), and organ weights (Supplementary Table 3-4) among these groups.

\section{Bioavailability of CSP}

Low bioavailability is one of the major hinders of curcuminoid to be applied as a therapeutic agent [18]. To assess the bioavailability of CSP, ICR mice were gavaged with low dose $(0.2 \mathrm{~g} / \mathrm{kg})$ or high dose $(2.5 \mathrm{~g} / \mathrm{kg})$ of unnanosized curcuminoids (C) or curcuminoid submicron particle (CSP), and their plasma were collected at 0,15 , $30,45,60,120$, and 300 minutes after gavaging. The level of un-nanosized curcuminoids or CSP in plasma was determined by high-pressure liquid chromatography (HPLC). The pharmacokinetic analysis indicated that the CSP had 35-folded higher absorbability than un-nanosized curcuminoids in high dose group (Table 1), illustrating that reducing the particle size could effectively improve the pharmacokinetic properties of curcuminoids.

\section{CSP ameliorated spatial learning and memory deficit of APP mice}

The neuroprotective effects of CSP in vivo were examined using APP transgenic mouse (line J20), which generates high level of $A \beta$ [25] and has age-dependent functional and pathological deficits onset at 4 months of age [26, 27]. APP mice and wild-type (WT) littermate controls were administered with CSP or vesicle control at $0.75 \mathrm{mg} / \mathrm{ml}$ in drinking water starting at 3 months of age

A

\section{Short-term}

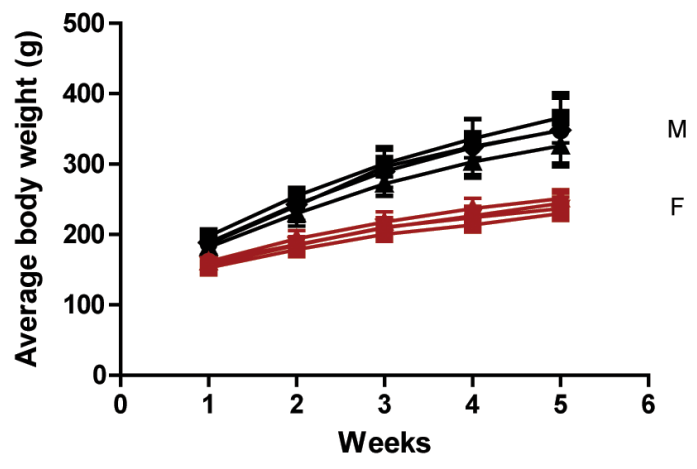

B

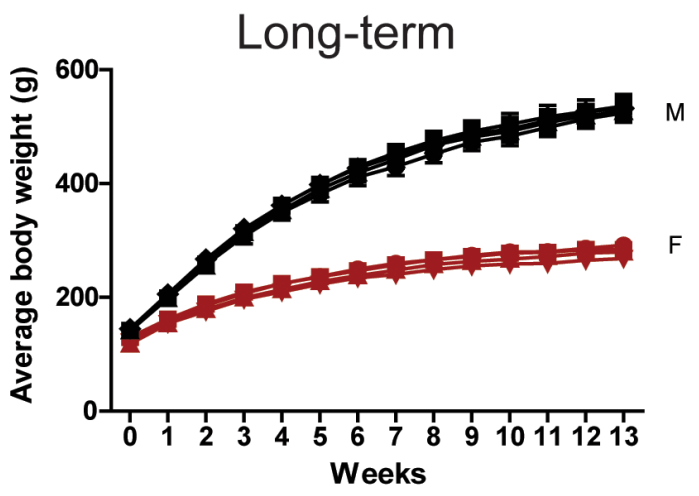

Figure 2: Body weight of SD rats in the oral toxicity study of CSP. Male (black) and female (red) SD rats received 0 (•), $0.1(\square)$, $0.5(\mathbf{\Delta})$, and $1(\boldsymbol{\nabla}) \mathrm{g} / \mathrm{kg} /$ day of CSP (A) for 28 days and (B) 90 days. $\mathrm{N}=6$ mice/group in 28-day test. $\mathrm{N}=8$ mice/group in 90 -day test. Results were analyzed by one-way ANOVA. 
Table 1: Pharmacokinetic analysis of un-nanosized curcuminoid (C) and curcuminoid submicron particle (CSP)

\begin{tabular}{lcccc}
\hline Treatment & $\begin{array}{c}\text { Dosage } \\
(\mathbf{g} / \mathbf{k g})\end{array}$ & $\begin{array}{c}\mathbf{C}_{\mathbf{m a x}} \\
(\boldsymbol{\mu g} / \mathbf{m l})\end{array}$ & $\begin{array}{c}\mathbf{T}_{\max } \\
(\mathbf{m i n})\end{array}$ & $\begin{array}{c}\text { AUC } \\
(\boldsymbol{\mu g} / \mathbf{m l} \mathbf{m i n})\end{array}$ \\
\hline C & 0.2 & $0.47 \pm 0.33$ & $45 \pm 11$ & $36 \pm 12$ \\
CSP & & $5.96 \pm 0.72$ & $75 \pm 42$ & $1,250 \pm 56$ \\
Ratio (CSP/C) & 12.62 & - & $48 \pm 7$ & $276 \pm 21$ \\
C & 2.5 & $1.83 \pm 0.19$ & $55 \pm 7$ & $1,884 \pm 57$ \\
CSP & & $12.70 \pm 1.01$ & - & 6.82 \\
Ratio $(\mathrm{CSP} / \mathrm{C})$ & & 6.96 &
\end{tabular}

$\mathrm{C}_{\max }$ : peak concentration. $\mathrm{T}_{\max }$ : time to reach peak concentration. AUC: area under curve (plasma concentration-time). $\mathrm{C}$ : curcuminoid. CSP: curcuminoid submicron particle. Quantitative data are listed as the mean \pm standard deviation.

for two months. The average amount of CSP consumption was $37.5 \mathrm{mg} / \mathrm{kg} /$ day. These mice had no significant difference in average body weight (Figure 3A) and water intake (Figure 3B) after 2 months treatment. AD-like functional and pathological deficits were examined in following four groups: wild-type fed with vesicle (WT), wild-type fed with CSP (WT/CSP), APP fed with vesicle, and APP fed with CSP (APP/CSP).

To elucidate whether CSP could improve cognitive impairment of APP mice [26, 28], the Morris water maze was adopted to evaluate spatial memory deficits the in these 4 groups of mice. In memory acquisition session, the escape latency to reach the hidden platform was longer in APP mice than WT mice. APP/CSP mice exhibited significantly shorter escape latency than APP mice in the last 4 days (Figure $4 \mathrm{~A}$ ). In probe trial for memory retention, APP mice spent significantly less time in the platform region than WT, and APP/CSP mice spent significantly longer time in the platform region than APP mice (Figure 4B-4C). There was no difference between WT and WT/CSP groups in all the tests. The swimming speeds among each group had no significant difference (Figure 4D), suggesting that the reverse of memory deficits in APP/CSP mice was not due the impairment in motor function. Our results demonstrated that CSP significantly improved both memory acquisition and the memory retention deficits in APP mice.

\section{CSP did not alter anxiety and locomotor behaviors of APP mice}

Before and after CSP consumption, we used the elevated plus maze to screen for anxiety-related behavior, and the open field test to monitor anxiety and locomotor activity. Compared with WT mice, APP mice spent more time in the open arm of the elevated plus maze (Figure 5A-5B), and traveled a longer distance and explored in the center region more frequently in the open field (Figure $5 \mathrm{C}-5 \mathrm{~F})$, consistent with previous findings $[12,27,28]$. In the elevated plus maze, 2 months of CSP treatment did not significantly reverse the higher open arm time in APP mice (Figure 5A-5B). Nevertheless, in the open field, 2 months of CSP treatment reduced the number of center entries (Figure 5C-5D) but did not alter the total distance moved in APP mice (Figure 5E-5F). Compared with WT mice, WT/CSP mice had no change in anxiety-related behavioral or locomotor activity. In summary, CSP did not influence locomotor activity and only partially reversed anxiety-related behavioral in APP mice.

\section{CSP reversed the calbindin- $\mathrm{D}_{28 \mathrm{~K}}$ level in the hippocampus of APP mice}

Memory deficits in APP mice are correlated with the reduced levels of a calcium-binding protein calbindin- $\mathrm{D}_{28 \mathrm{~K}}$ and calcium dysregulation in the dentate gyrus [26, 29]. Therefore, the expression of calbindin- $\mathrm{D}_{28 \mathrm{~K}}$ was used to as a marker to examine calcium homeostasis in our mice. We found that the level of calbindin- $\mathrm{D}_{28 \mathrm{~K}}$ was significantly reduced in APP mice compared to WT mice, but this reduction can be alleviated by CSP consumption in APP mice (Figure 6A-6D), implying that memory decline in APP mice rescued by CSP could be associated with the revered levels of calbindin- $\mathrm{D}_{28 \mathrm{~K}}$ in the dentate gyrus.

\section{CSP decreased the amyloid level and astrogliosis in the hippocampus of APP mice}

$A \beta$ deposition is one of the most important pathological hallmarks of AD. Among different length of $A \beta$ peptides, $A \beta 42$ is more aggregation-prone and more neurotoxic than other $A \beta$ species [3]. To investigate whether CSP alters A $\beta$ level in APP mice, we monitored the appearance of amyloid plaques with thioflavin-S staining and the level of $A \beta$ with enzyme-linked immunosorbent assay (ELISA). The number of amyloid plaques (Figure 7A-7B) and the level of A $\beta 42$ (Figure 7C) were significantly decreased in the hippocampus of APP/ CSP mice compared to those of APP mice. However, there were no significant reductions in total $A \beta$ level (Figure 
A

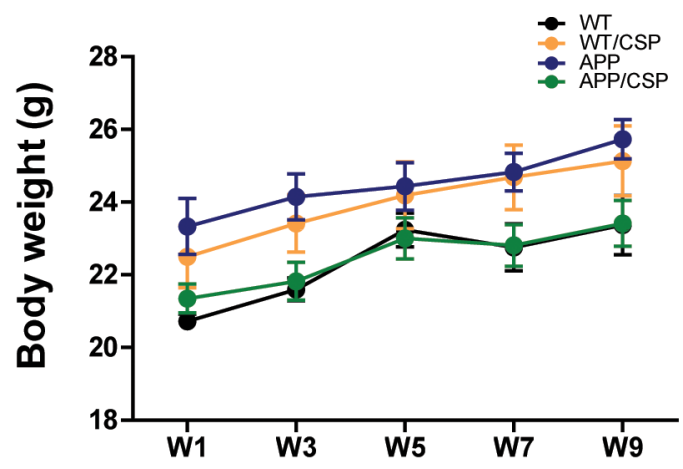

B

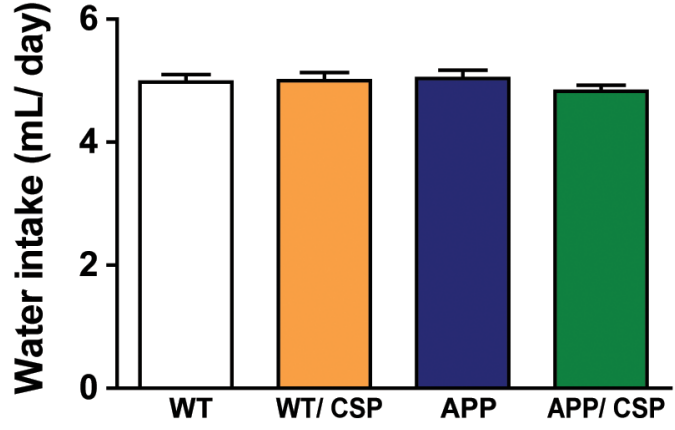

Figure 3: Body weight and water intake of WT and APP mice during CSP treatment. APP and wildtype littermate control (WT) mice received 0 or $0.75 \mathrm{mg} / \mathrm{mL} /$ day of CSP for 2 months. (A) Body weight and (B) water intake were recorded weekly during CSP administration. $\mathrm{N}=12-17$ mice/group. Results were analyzed by one-way ANOVA.

A

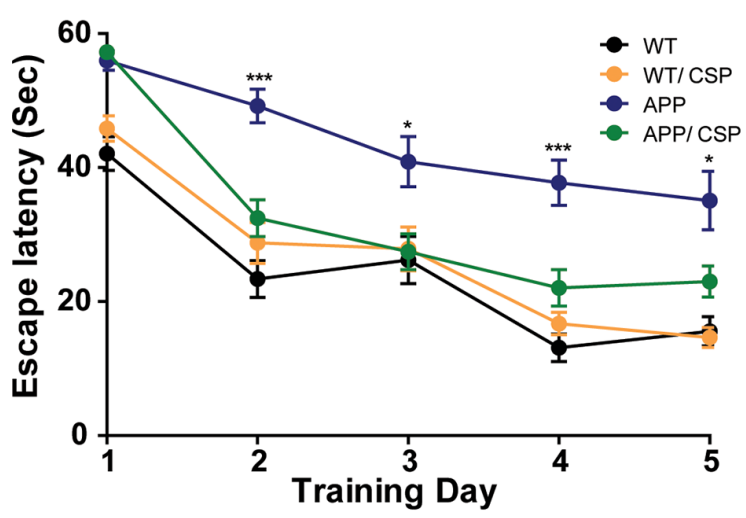

C

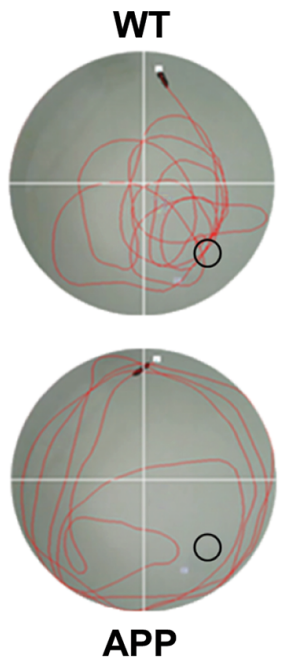

B

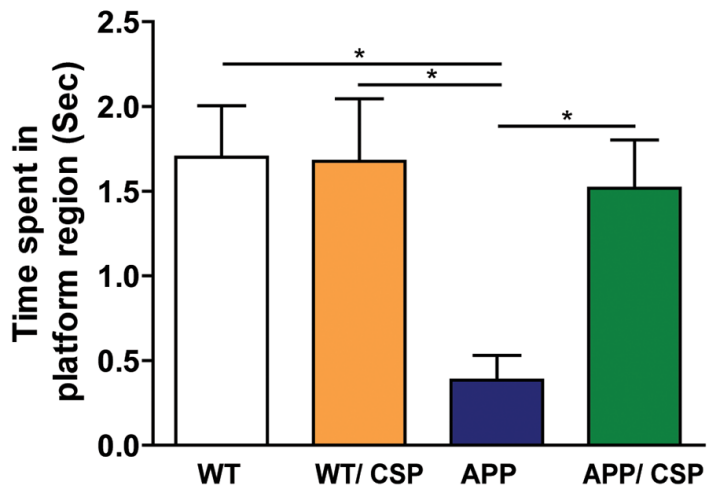

$\mathrm{D}$

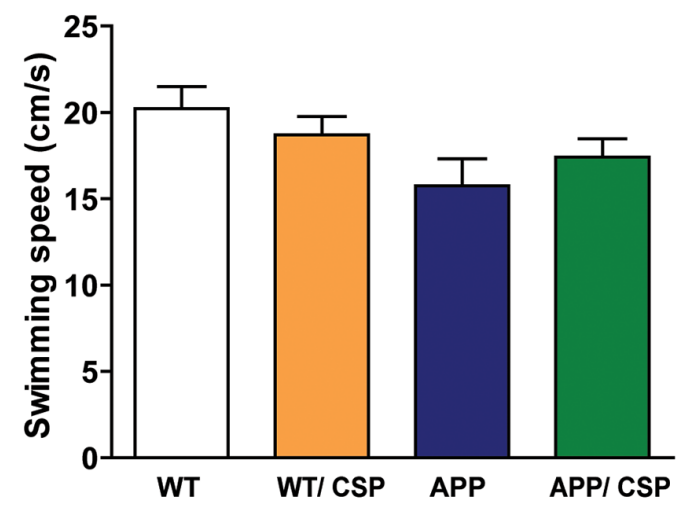

Figure 4: CSP ameliorated the spatial learning and memory of APP mice in the Morris water maze. (A) In hidden platform test, APP/CSP mice had a lower escape latency than APP mice given the control diet. (B) In probe trial, APP/CSP mice spent more time in platform region than APP mice. (C) Representative traces of each group in the probe trial. $\circ=$ platform location. (D) Swimming speed had no significant difference among all four groups. $\mathrm{N}=12-17$ /group. Results were analyzed by one-way ANOVA. ${ }^{*}, \mathrm{p}<0.05 ;{ }^{* * *}, \mathrm{p}<0.001$. 


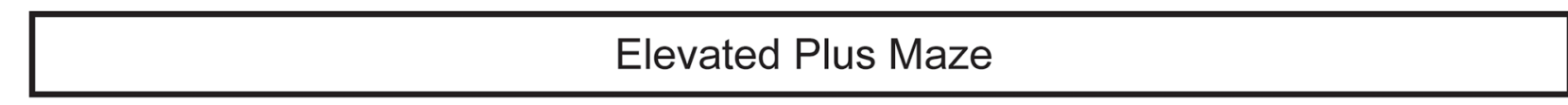

A

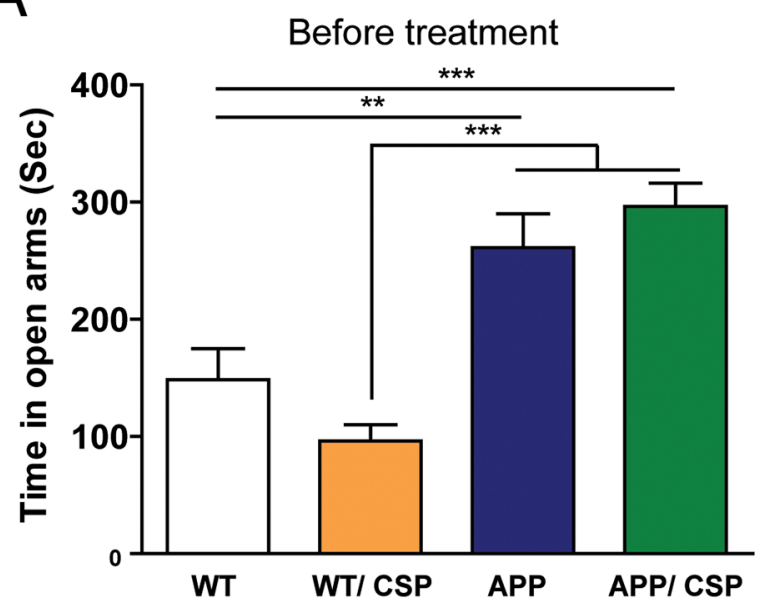

B

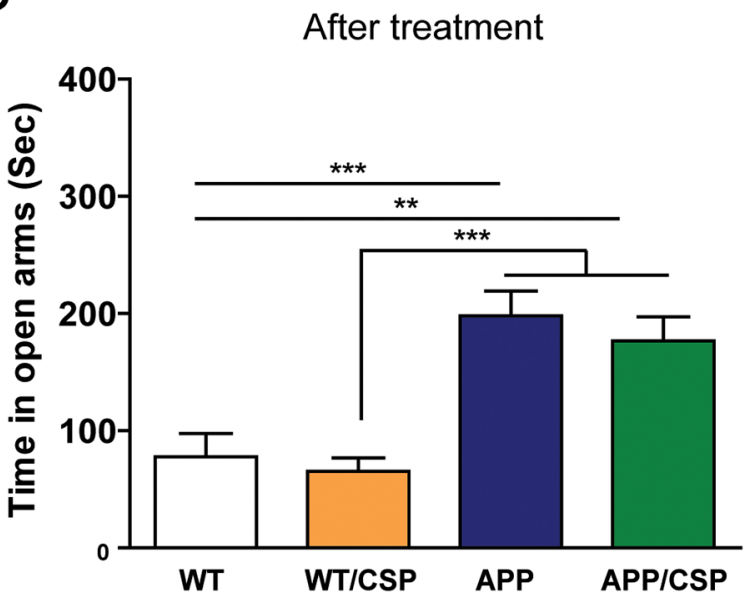

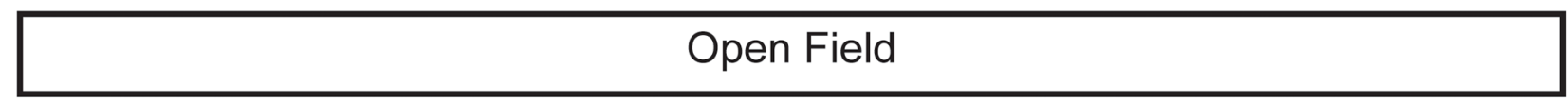

C

Before treatment

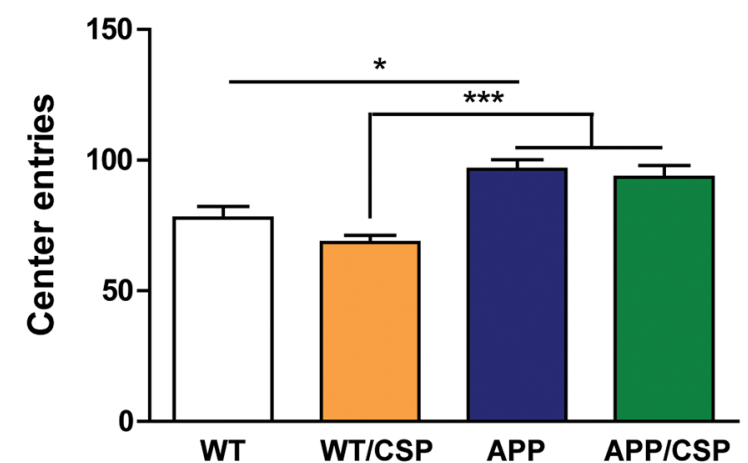

$E$

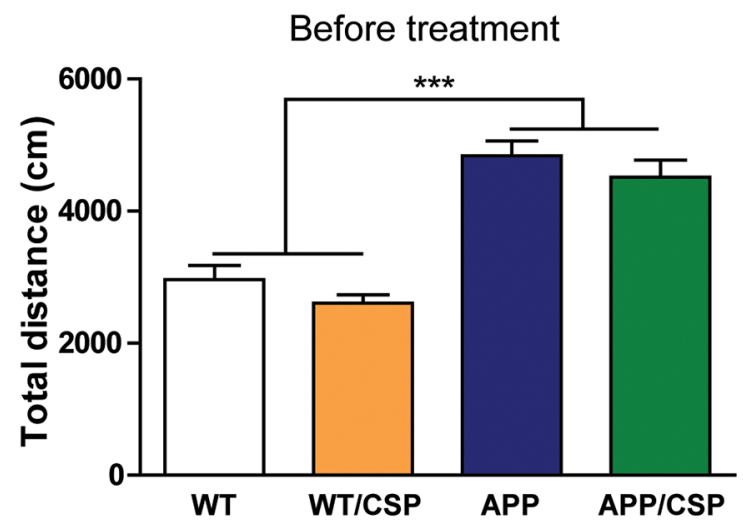

D

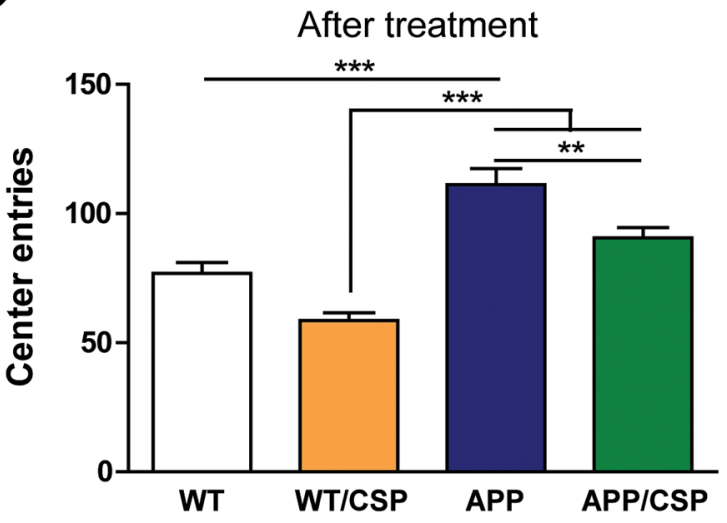

$\mathrm{F}$

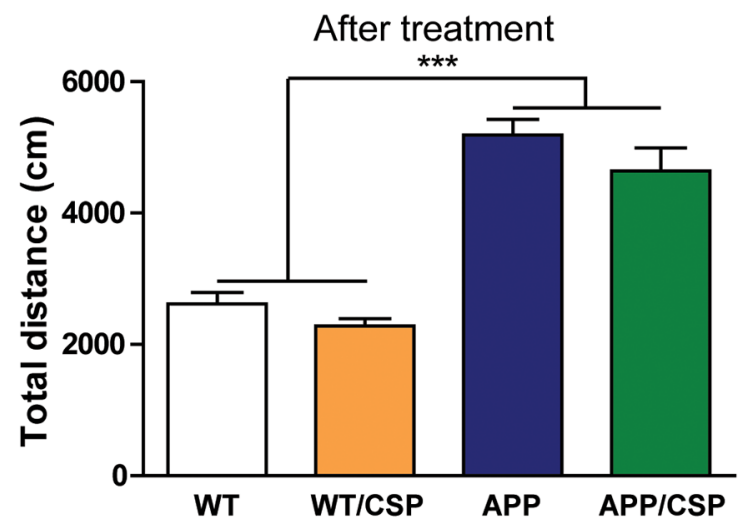

Figure 5: Effect of CSP on anxiety-related behavior and locomotor activities of APP mice. (A-B) In elevated plus maze, anxiety behavior of these mice was measured by time in open arms before (A) and after (B) CSP treatment. (C-F) In open field, anxiety was measured by the number of center entries (C, D) and locomotor activity was measured by total distance traveled (e, f) before and after CSP consumption. $\mathrm{N}=12-17$ mice/group. Results were analyzed by two-way ANOVA. ${ }^{*}, \mathrm{p}<0.05 ;{ }^{* *}, \mathrm{p}<0.01 ;{ }^{* * *}, \mathrm{p}<0.001$. 

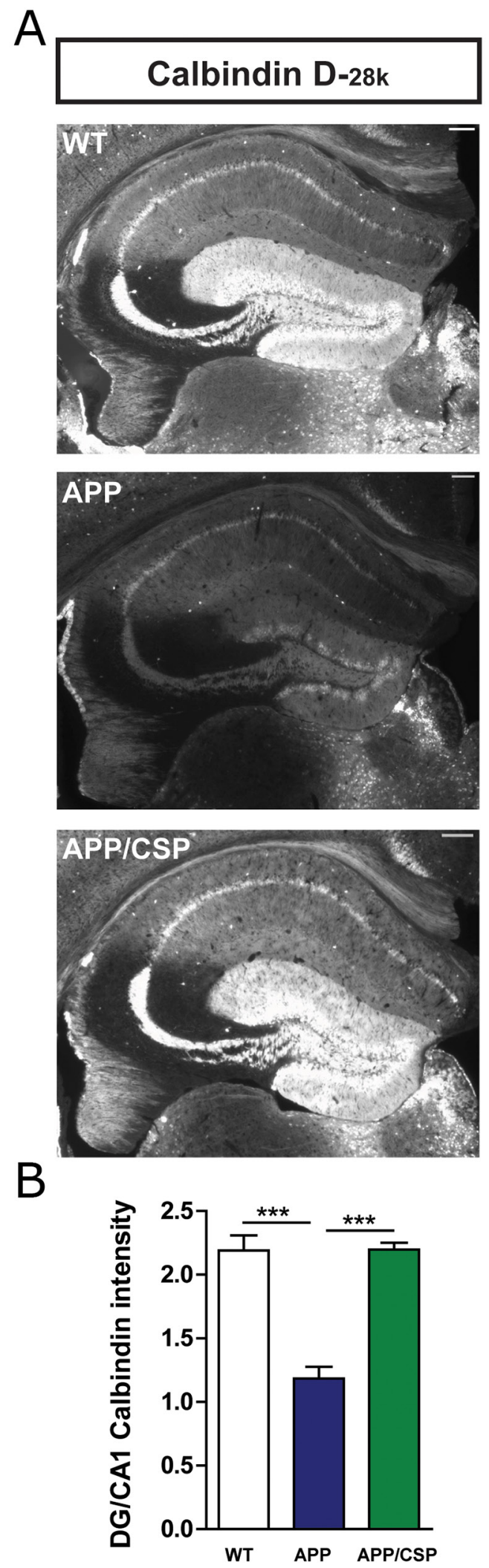

Figure 6: CSP reversed the calbindin- $\mathrm{D}_{28 \mathrm{~K}}$ level in the hippocampus of APP mice. (A) Representative calbindin- $\mathrm{D}_{28 \mathrm{~K}}$ images in the hippocampus of WT, APP, APP/CSP mice. (B) Normalized intensity of calbindin- $\mathrm{D}_{28 \mathrm{~K}}$ in the dentate gyrus of the hippocampus in each group. $\mathrm{N}=6$ mice/group, $8-10$ brain slices per mouse. Results were analyzed by one-way ANOVA. ${ }^{* * *}, \mathrm{p}<0.001$. Scale bar $=200 \mu \mathrm{m}$. 
7D) and $A \beta 42$ to total $A \beta$ ratio (Figure 7E) between APP/ CSP mice and APP mice. These results indicated that CSP could effectively inhibit the amyloid and neurotoxic $\mathrm{A} \beta$ 42 levels in AD.

In addition to amyloid pathology, the inflammatory response in these mice was measured by the activation of astrocyte or microglia. The immunoreactive signals of glial fibrillary acidic protein (GFAP) and ionized calcium-binding adapter molecule 1 (Iba1) were used as astrocyte and microglial markers [30]. We found that APP mice had higher GFAP and Ibal intensity than WT mice. Consumption of CSP reduced the intensity of
GFAP positive astrocyte in the hippocampus of APP/CSP mice (Figure 8A-8B). CSP did not alter the intensity of Iba1-positive microglia in the hippocampus of APP mice (Figure 8C-8D). Taken together, CSP could mitigate amyloid pathology and inflammatory reaction in APP mice.

\section{CSP promoted the microglial phagocytosis and $\mathrm{A} \beta$ uptake in $\mathrm{BV}_{2}$ microglia}

Microglia activation could promote phagocytosis to clear $\mathrm{A} \beta$. Although $\mathrm{CSP}$ did not reduce activated
A
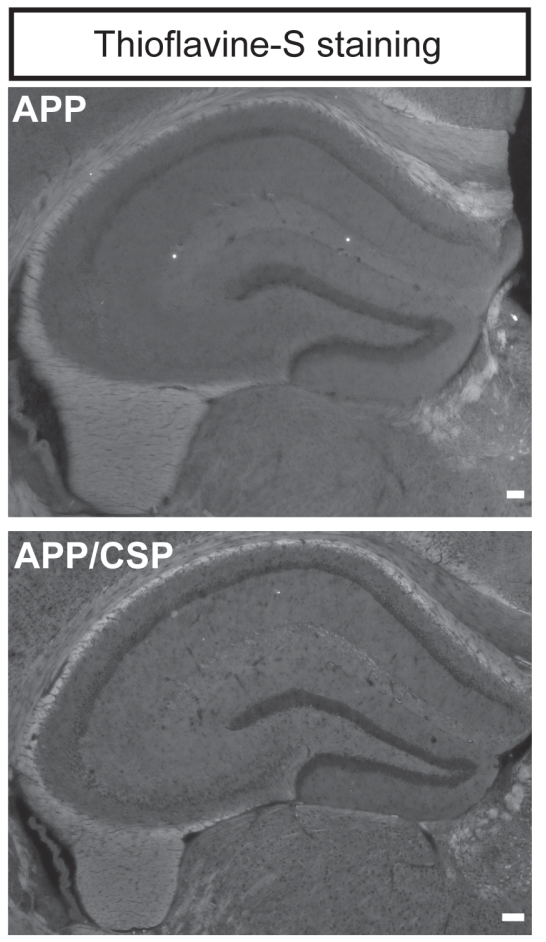

B

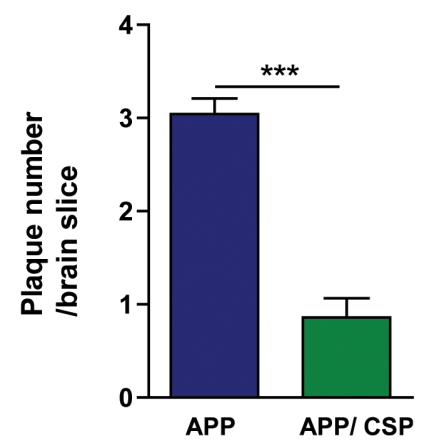

C

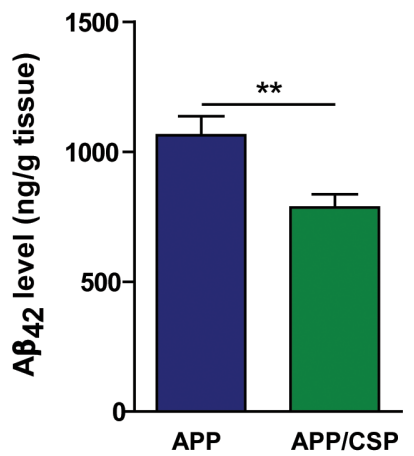

D

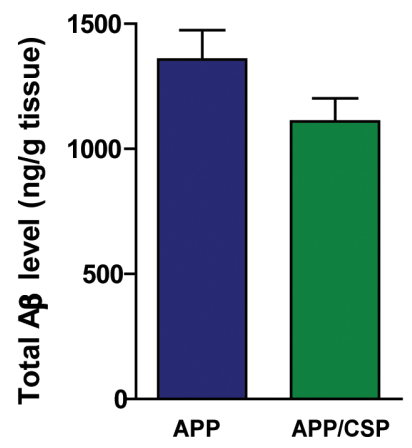

E

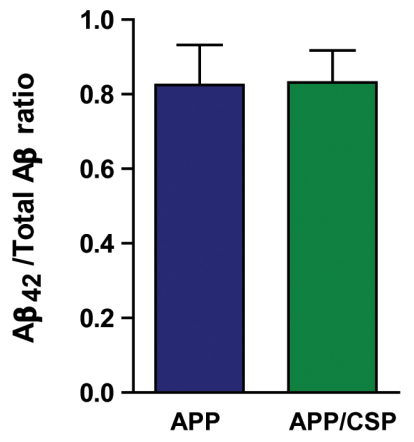

Figure 7: CSP decreased the amyloid deposition in the hippocampus of APP mice. (A) Representative images of $\beta$-sheet amyloid plaques in the hippocampus of APP and APP/CSP mice stained by Thioflavin-S. Scale bar $=200 \mu \mathrm{m}$. (B) Quantitative analysis of the number of the plaques in the hippocampus. $N=6$ mice/group, $6-10$ slices per mouse. (C-D) The levels of $A \beta 42$ (C) and total $A \beta$ (D) in the hippocampal lysate were determined by ELISA. (E) A $\beta 42 /$ total A $\beta$ were unchanged in APP mice treated with CSP. N = 13-17 mice/ group. Results were analyzed by $t$ test. ${ }^{* *}, \mathrm{p}<0.01 ;{ }^{* * *}, \mathrm{p}<0.001$ versus APP mice. 
A
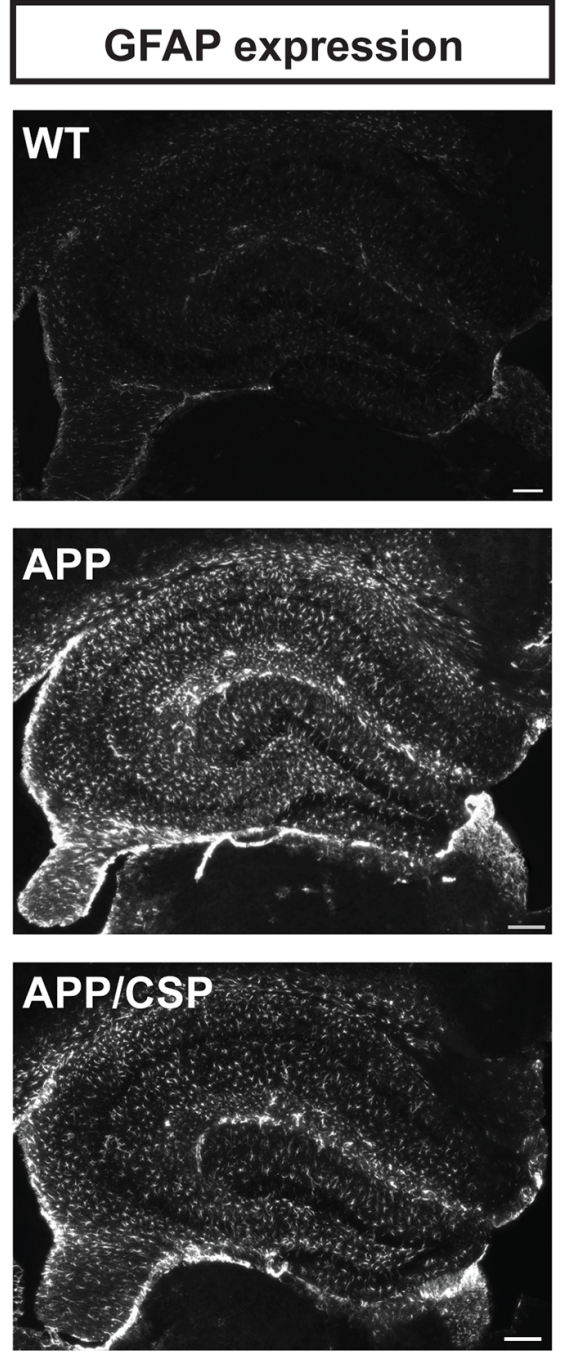

B

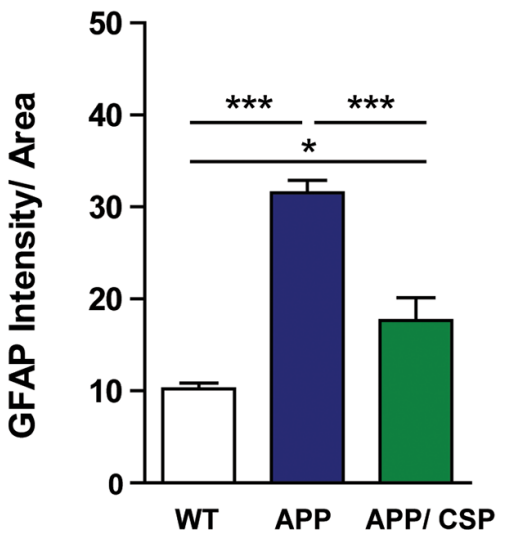

C
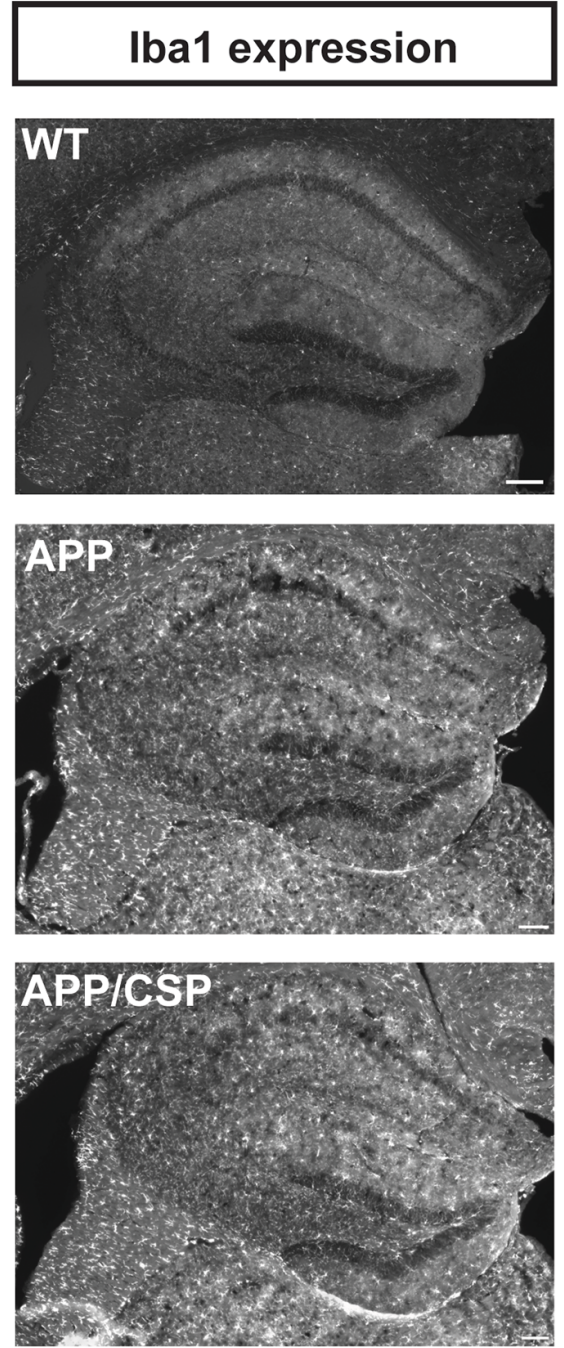

$\mathrm{D}$

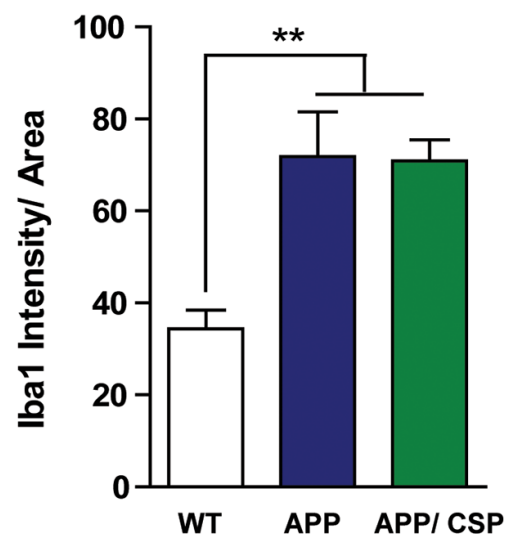

Figure 8: CSP inhibited astrocyte activation in the hippocampus of APP mice. (A) Representative images of GFAP ${ }^{+}$astrocyte activation in the hippocampus of WT, APP and APP/CSP mice. (B) Normalized GFAP intensity in the hippocampus in each group. (C) Representative images of $\mathrm{Iba1}^{+}$microglia in the hippocampus of WT, APP and APP/CSP mice. (D) The normalized Iba1 intensity in the hippocampus in each group. $\mathrm{N}=6$ mice/group, $8-10$ brain slices per mouse. Results were analyzed by one-way ANOVA. ${ }^{*}, \mathrm{p}<0.05 ;{ }^{* *}, \mathrm{p}$ $<0.01 ; * *, p<0.001$. Scale bar $=200 \mu \mathrm{m}$. 
microglia, CSP decreased the number of plaques in the hippocampus of APP mice. Therefore, we further identified whether CSP could affect the $\mathrm{A} \beta$ clearance through enhancing the microglial phagocytosis [3]. To address this question, the $\mathrm{BV}_{2}$ microglial cell was treated with 0 or $2.2 \mu \mathrm{M}$ CSP for 1 hour and followed by adding $0.001 \%$ fluorescent microspheres beads (Figure 9A9B). We found that CSP treated cells had significantly higher percentage of phagocytosed cells (Figure 9C). Furthermore, after co-incubating oA $\beta$ with or without CSP, the $A \beta$ level in the medium of $A \beta+C S P$-treated microglia was significantly lower than $A \beta$ only microglia (Figure 9D). These results demonstrated that CSP enhances the A $\beta$-clearance ability of microglia, thereby ameliorating A $\beta$-induced neurodegeneration.

We further determined whether CSP could modulate the ratio of $\mathrm{M} 1 / \mathrm{M} 2$ phenotype of microglia. The exposure of BV2 to $5 \mu \mathrm{M}$ oA $\beta$ could significantly increase the inducible nitric oxide synthase (iNOS), which is one of the direct consequences of an inflammatory process and commonly uses as a marker for M1 microglia [31, 32]. The iNOS level was decreased in $\mathrm{BV}_{2}$ microglia co-treated with $2.2 \mu \mathrm{M}$ CSP and oA $\beta$ (Figure 10A-10B). However, there was no change in $\mathrm{M} 2$ anti-inflammatory markers YM1 and IL-4 (Figure 10C-10D). These results suggested that CSP may decrease neuroinflammation but did not alter M1/M2 microglia phenotypes.
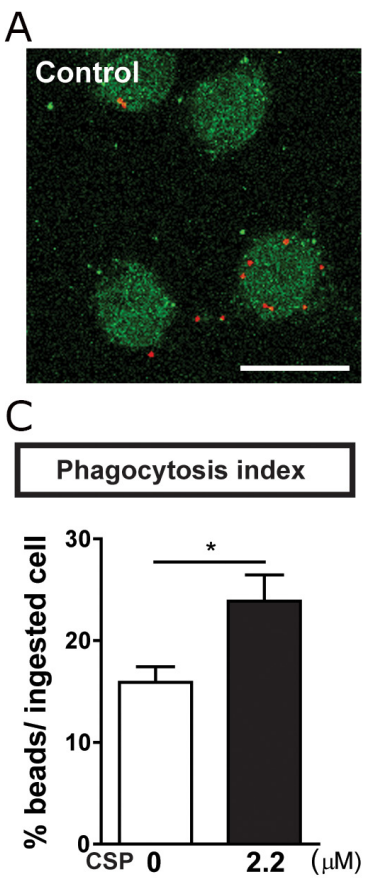

\section{CSP did not have anti-aggregation effect on A $\beta$}

The reduced A $\beta$ level in APP/CSP mice may also due to the inhibition of $A \beta$ aggregation by CSP. Curcumin has been reported to reduce the amounts of higher molecular $A \beta$ aggregates [16]. To monitor the effect of CSP on $\mathrm{A} \beta$ aggregation, $5 \mu \mathrm{M}$ monomeric $\mathrm{A} \beta$ was incubated with $0,22,44,220,440 \mu \mathrm{M}$ CSP for 24 and 48 hours and subjected to immunoblot analysis. We found that $A \beta$ aggregates into high molecular weight assemblies $(>180 \mathrm{kDa})$ faster in the presence of CSP, indicating that the reduction of $A \beta$ deposition in the APP/CSP mice is not due to the blockage of $A \beta$ aggregation (Figure 11).

\section{DISCUSSION}

This study demonstrated that the nano-sized curcuminoid, CSP, had higher bioavailability and better neuroprotective effects than un-nanosized curcuminoid. CSP treatment significantly ameliorated the cognitive function, reduced the amyloid deposition, decreased astrogliosis, reversed calbindin- $\mathrm{D}_{28 \mathrm{k}}$ and enhanced microglial phagocytosis. These findings indicate that CSP has potential to be applied as a prevention agent for AD. Curcumin and curcuminoid do not induce apparent adverse effects up to $8,000 \mathrm{mg}$ /day in healthy adults [3335]. We demonstrated that both short term and long term

\section{B}

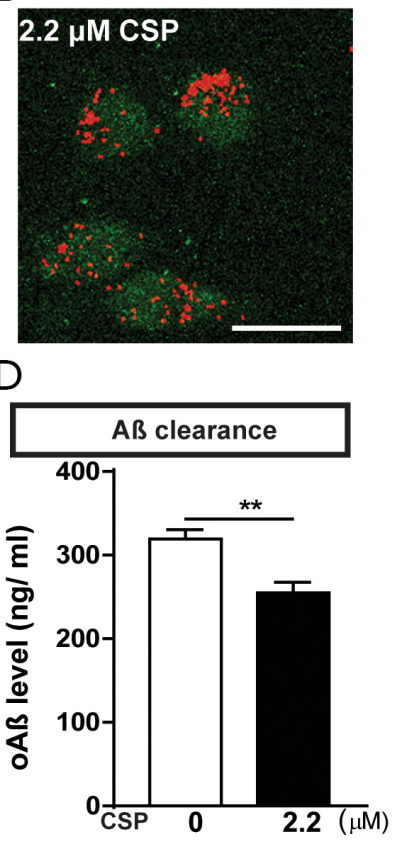

Figure 9: CSP increased phagocytosis of $\mathbf{B V}_{2}$ microglia. (A-B) Representative images of ingested microspheres (red) in the $\mathrm{BV}_{2}$ cells (green) treated with 0 or $2.2 \mu \mathrm{M}$ CSP for $1 \mathrm{hr}$. Scale bar $=25 \mu \mathrm{m}$. (C) CSP significantly increased the phagocytosis index. $\mathrm{N}=11,480$ cells in control group; $\mathrm{N}=18,199$ cells in CSP treated group. (D) $\mathrm{BV}_{2}$ cells were treated with $1 \mu \mathrm{M}$ oA $\beta$ and 0 or $2.2 \mu \mathrm{M}$ CSP for 24 hrs. Levels of residual A $\beta$ in the media were lower in the CSP treated group. Results were analyzed by $t$ test. ${ }^{*}, \mathrm{p}<0.05 ;{ }^{* *}, \mathrm{p}<0.01$. 
A

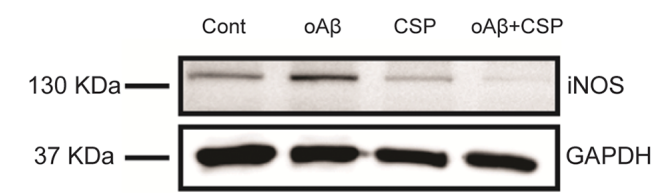

C

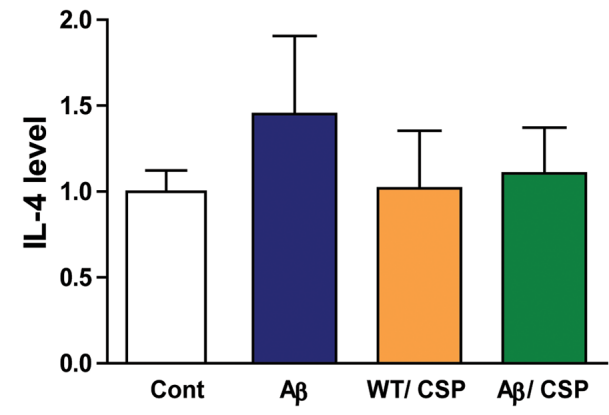

B

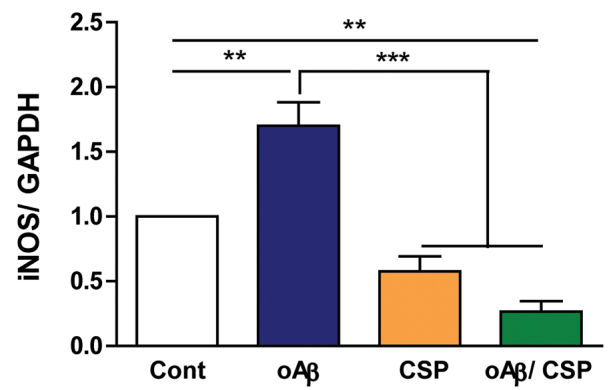

$\mathrm{D}$

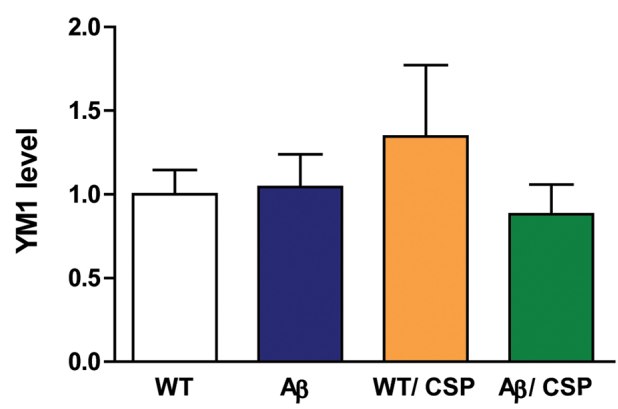

Figure 10: CSP reduced the $M 1$ but did not change the $M 2$ type of microglia under $\mathrm{oA} \beta$ stress. $\mathrm{BV}_{2}$ microglia was treated with $5 \mu \mathrm{M}$ oA $\beta$ and $2.2 \mu \mathrm{M}$ CSP for 24 hours. (A) Representative immunoblot images for pro-inflammatory M1 type microglia marker iNOS in $\mathrm{BV}_{2}$ cells. (B) The level of iNOS in $\mathrm{oA} \beta+\mathrm{CSP}$ treated microglia was significantly lower than oA $\beta$ treated microglia. (C-D) Expression of anti-inflammatory M2 type microglia markers YM1 and IL-4 RNA had no significant difference among all groups. Results were analyzed by one-way ANOVA. ${ }^{* *}, \mathrm{p}<0.01 ;{ }^{* * *}, \mathrm{p}<0.001$.

A

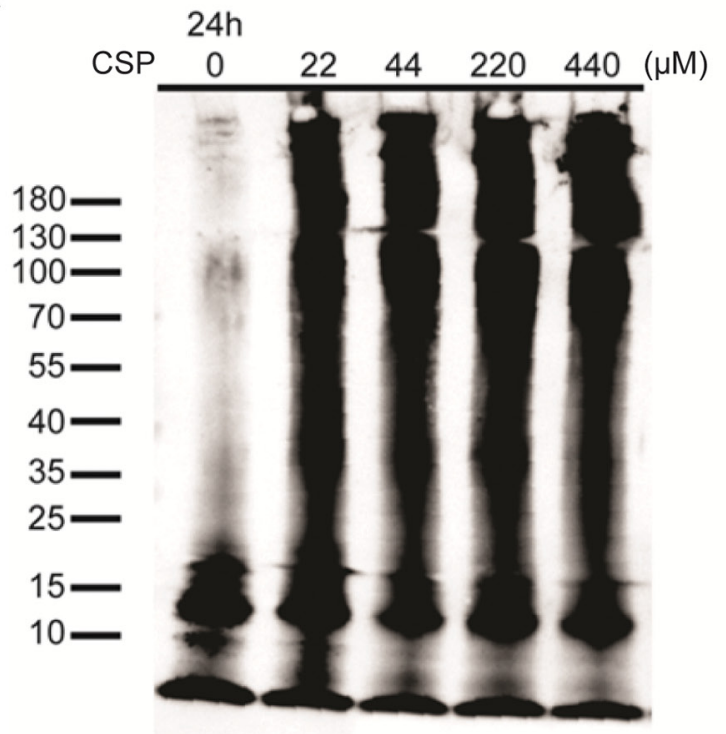

B

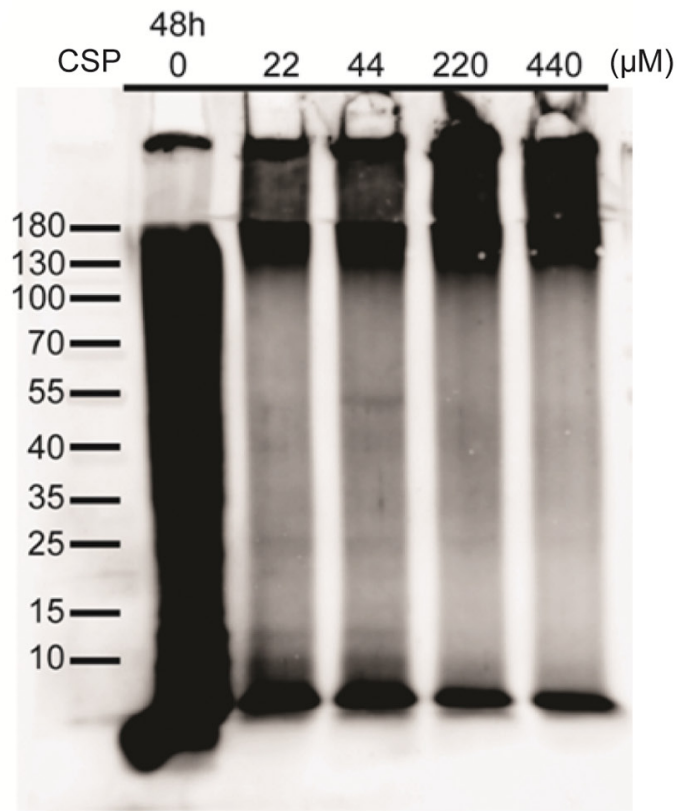

Figure 11: CSP did not inhibit A $\beta$ aggregation in vitro. Representative images of $A \beta$ aggregation states in the presence of CSP. $5 \mu \mathrm{M}$ monomeric $\mathrm{A} \beta$ were co-incubated with $0,22,44,220$, and $440 \mu \mathrm{M}$ CSPs for (A) 24 hours and (B) 48 hours. The size distribution of aggregated $\mathrm{A} \beta$ was immediately examined by western blot. 
CSP consumption is safe under $1000 \mathrm{mg} / \mathrm{kg} / \mathrm{day}$. In this study, the amount of CSP consumption for the mouse was $187.5 \mathrm{mg} / \mathrm{kg} / \mathrm{day}$, which is approximately equated to $15.2 \mathrm{mg} / \mathrm{kg} /$ day for human [36]. For a $60 \mathrm{~kg}$ adult, daily intake of CSP needs to be $912 \mathrm{mg}$ to reach the similar neuroprotective effect, which is within the safe range for curcuminoid [37-39].

Multiple approaches have been applied to increase the bioavailability and enhance the neuroprotective effect of curcumin or curcuminoid. The two most common approaches were structural modification and size reduction [22-24]. After oral gavage, the plasma concentration of CSP was 6-35 times higher than unnanosized curcuminoid, which is similar or even better than the bioavailability of curcumin modified by other approaches [22-24]. Whether curcumin could reverse the memory-related deficits in AD mouse models have diverse results. In other curcumin treated $\mathrm{AD}$ mouse model, although curcumin could reverse working memory deficits in Y-maze test $[38,40]$, it did not significantly improve the memory retention deficits in the probe trial of the Morris water maze test, which is more related to the condition in $\mathrm{AD}$ patients $[37,39,41]$. The PLGA nanoparticles modified curcumin could only attenuate memory deficits when co-delivering with $\mathrm{A} \beta$ generation inhibitor through intraperitoneal injection to $\mathrm{AD}$ mouse model [42]. In our study, APP/CSP mice performed significantly better in both hidden platform and probe trial tests, suggesting that the improvement in both memory acquisition and retention of $\mathrm{AD}$ mouse model. Our results indicated that the therapeutic efficacy of orally administered CSP was greatly increased in comparison with previous studies.

$A \beta$-induced neuroinflammation is mostly mediated through CNS-resident cells, including astrocyte and microglia, rather than invading immune cells [43]. Reactive astrocytes cause disruptions in synaptic connectivity, imbalance of neurotransmitter homeostasis, and neurodegeneration in AD [44, 45]. Furthermore, the degree of astrogliosis is correlated with cognitive decline in the brain of $\mathrm{AD}$ patients [46]. In our study, CSP could inhibit reactive astrocyte activation in APP mice, suggesting that CSP could reduce astrocyte-mediated neuroinflammation. On the other hand, although CSP consumption did not alter the intensity of $\mathrm{Iba}^{+}$microglia in APP mice, CSP treatment enhanced phagocytic percentage in $\mathrm{BV}_{2}$ microglia cells. Therefore, the reduction of amyloid plaques in the hippocampus of APP mice might be mediated by CSP through the microglial engulfment. Dysfunction of microglial phagocytosis in AD patients has been linked to the disrupted clearance of $A \beta$, and the enhanced memory impairment $[47,48]$. A curcuminoid compound (bisdemethoxycurcumin) has been shown to increase the $\mathrm{A} \beta$ phagocytosis in the brains of AD patients [49]. Our results provided consistent evidence that CSP enhances microglial phagocytosis.
Calcium-binding proteins could regulate calcium homeostasis and protect neuron against calcium-mediated neurotoxicity [50]. The disruption of calcium-binding proteins signaling impairs the synaptic function [51]. In the hippocampus, calbindin- $\mathrm{D}_{28 \mathrm{k}}$ containing neurons play roles in memory formation and long-term potentiation [52]. The level of calbindin- $\mathrm{D}_{28 \mathrm{k}}$ is highly correlated with memory retention deficits of APP mice [26]. In our study, the reduced expression of calbindin- $\mathrm{D}_{28 \mathrm{k}}$ in APP mice was reversed after CSP consumption, which provided the first indication linking the effects of curcuminoid to the levels of calbindin- $\mathrm{D}_{28 \mathrm{k}}$ in $\mathrm{AD}$ model.

In summary, this study demonstrated the beneficial effects of CSP on spatial memory deficits and pathological changes in APP mice. CSP can be easily administered to animal model in drinking water as a stable suspension without noticeable adverse effects. Altogether, CSP could be a potential food supplement for long-term treatment of AD.

\section{MATERIALS AND METHODS}

\section{Animals}

Short-term (28-day) and long-term (90-day) biosafety tests were performed on male and female SD rats. Micronucleus assay was performed on ICR mice. AD mouse model used in this study is APP transgenic mice (line J20) carrying the human APP minigene with the Swedish (K670N/M671L) and Indiana (V717F) familial mutations. Animals were housed in a specific pathogenfree facility with a light/dark cycle of 12 hours light and 12 hours dark. Food and water for mice were provided ad libitum. Drinking water with $0.75 \mathrm{mg} / \mathrm{mL}$ CSP was administrated for mice from 3 to 5 months of ages. The open field and elevated plus maze were performed before and after treatment, and the Morris water maze was carried out after 2 months of CSP consumption. Mice were sacrificed with transcardial perfusion with $0.9 \% \mathrm{NaCl} 2$ days after behavioral tests. One hemibrain was drop-fixed in $4 \%$ paraformaldehyde for $48 \mathrm{~h}$, and the other hemibrain immediately froze at $-70^{\circ} \mathrm{C}$. The study was approved by the Institutional Animal Care and Use Committee of National Yang-Ming University. All experimental procedures involving animals and their care were carried out in accordance with the Guide for the Care and Use of Laboratory Animals published by the United States National Institutes of Health.

\section{Preparation of aqueous dispersion with CSP}

To prepare stabilizer for CSP, $2.5 \mathrm{~g}$ L- $\alpha$ phosphatidylcholine (P7443, Sigma, USA) and 3.42 g sucrose esters (Gemfont Corporation, Taiwan) were sequentially incorporated into $400 \mathrm{~mL}$ water. The mixed stabilizer materials were stirred at $25^{\circ} \mathrm{C}$, and $40 \mathrm{~g}$ 
curcuminoid powder with curcumin, demethoxycurcumin, and bisdemethoxycurcumin (Toong Yeuan, Taiwan) were added to form a $10 \%$ curcuminoid aqueous solution. This non-homogenously mixed solution was subjected to a high-speed homogenization pretreatment from 4,000 to $6,000 \mathrm{~g}$ for 10 minutes using a PRO250 homogenizer (PRO Scientific, USA). Next, a nano-grade wet grinder (Netzsch-Fein mahltechnik GmbH, Germany) carried on yttria-stabilized tetragonal zirconia for circulation milling with $0.2 \mathrm{~mm}$ beads for 180 minutes to obtain the aqueous dispersion. The average diameter of un-nanosized curcuminoid was $5140 \pm 178 \mathrm{~nm}$, and the average diameter of CSP was $59 \pm 1 \mathrm{~nm}$. Finally, the nanosized CSP composed of curcumin $(83.56 \%)$, demethoxycurcumin (14.13\%) and bisdemethoxycurcumin (2.31\%) was obtained. Right before oral administration, CSP was diluted into the drinking water at concentration $0.75 \mathrm{mg} / \mathrm{mL}$. The vesicle control in this study contain the same stabilizer and went through the same preparation process without adding curcuminoid.

\section{Bioavailability and biosafety analysis}

For the pharmacokinetics analysis, ICR mice were administered by oral gavage with $0.2 \mathrm{~g} / \mathrm{kg}$ or $2.5 \mathrm{~g} / \mathrm{kg}$ of un-nanosized curcuminoid or CSP. At 15, 30, 45, 60, 120 , and 300 minutes after gavage, plasma was collected and processed with sulfatase for 2 hours. The level of curcuminoid in plasma was determined by high-pressure liquid chromatography (HPLC).

For biosafety test, including genotoxic analysis, shortterm and long-term tests were adopted to investigate the potentially harmful effects of CSP. Micronucleation assay was applied to identify the genotoxicity of CSP. ICR mice were administered orally with $0,0.03,0.3,3.0 \mathrm{~g} / \mathrm{kg}$ of CSP or $0.1 \mathrm{~g} / \mathrm{kg}$ cyclophosphamide (positive control) for 48 hours. $200 \mu \mathrm{L}$ plasma was incubated with $50 \mu \mathrm{L} 100 \mathrm{U} / \mathrm{mL}$ sulfatase for 2 hours, and $120 \mu \mathrm{L}$ processed sample was then fixed by frozen methanol $\left(-80^{\circ} \mathrm{C}\right) .12 \mathrm{~mL}$ buffer $(1.8 \mathrm{~g} \mathrm{NaCl}$ and $0.089 \mathrm{~g} \mathrm{NaHCO}_{3}$ in $200 \mathrm{~mL}$ sterile water, $4^{\circ} \mathrm{C}$ ) was added to the fixed sample and centrifuged at $1,000 \times \mathrm{g}$ for 5 minutes to remove supernatant. Cells were resuspended with $80 \mu \mathrm{L}$ buffer (10 $\mu \mathrm{L} / \mathrm{mL}$ CD71-FITC and $1 \mathrm{mg} / \mathrm{mL}$ RNAase) for 30 minutes at $4{ }^{\circ} \mathrm{C}$, and then $1 \mathrm{~mL}$ protease inhibitor $(2.5 \mu \mathrm{g} /$ $\mathrm{mL}$ ) was added. The percentage micronucleated reticulocyte in their blood will be analyzed by Flow cytometric-Becton Dickinson FacsCalibur and Cell Quest.

In short-term and long-term safety tests, SD rats were administered with $0.1,0.5$ and $1.0 \mathrm{~g} / \mathrm{kg} / \mathrm{day}$ CSP, or sterile water, daily for 28 days and 90 days. The clinical condition, body weights, organ weights studies were performed after 28 days and 90 days.

\section{Morris water maze}

The water maze consisted of a water pool (122 $\mathrm{cm}$ in diameter) containing opaque water and a platform (10 $\mathrm{cm}$ in diameter) submerged $1 \mathrm{~cm}$ below the water surface. The hidden platform test consisted of 10 sessions over 5 days, and each session comprised three 60 -second trials with 15-minute inter-trial intervals. The platform location remained constant during the hidden platform sessions, and the entry points were changed semi-randomly between days. One day after the final day of hidden platform training section, a probe trial was conducted by removing the platform and allowing mice to explore in the pool for 1 minute. The time spent in platform region and swim speed were recorded and analyzed with an EthoVision video tracking system (Noldus, Wageningen, Netherlands).

\section{Elevated plus maze}

Elevated plus maze consists of two open arms, two closed arms, and a center area. Mice were habituated in the testing room for 1 hour and then were placed individually at the center of the apparatus to explore for 10 minutes. The time spent and distances moved in each of the arms were recorded and analyzed with an EthoVision video tracking system.

\section{Open field}

Mice were habituated in the testing room for 1 hour and were placed in an open arena $\left(24.32 \times 24.32 \mathrm{~cm}^{2}\right)$ for 15 minutes. Two infrared photobeam sensor frames, each consisting of a $32 \times 32$ photobeam array, were used to detect movements in the horizontal and vertical plane (Version 2.0, TRU Scan Photobeam LINC, Coulbourn Instruments, PA, USA). The distance mice traveled and center entries were used as parameters to analyze the general activity and anxiety of mice.

\section{Enzyme-linked immunosorbent assay (ELISA)}

Frozen hippocampi were homogenized in $5 \mathrm{M}$ guanidine $/ 5 \mathrm{mM}$ Tris buffer $(\mathrm{pH} 8.0)$. The samples were diluted with $0.25 \%$ casein blocking buffer containing 0.5 M guanidine and protease inhibitor mix (04693116001, Roche, Switzerland). Total $A \beta$ and $A \beta 42$ levels in the soluble fraction were analyzed with ELISA kits (27729 and 27711, INL, Germany) according to the manufacturer's instructions.

\section{Immunohistochemistry and thioflavin-S staining}

Paraformaldehyde-fixed brains were sectioned coronally (at $20 \mu \mathrm{m}$ thickness) using a sliding microtome (CM1900; Leica, Germany). For immunohistochemistry (IHC), slices were blocked with phosphate-buffered saline (PBS) containing $10 \%$ fetal bovine serum (FBS) and $0.5 \%$ Triton X-100 for 1.5 hours, and incubated with antiGFAP (Z0334; Dako Cytomation, Denmark), anti-Iba1 (019-19741; Wako, Japan), anti-YM1 (\#01404, Stemcell Technologies, Canada) and anti-Calbindin- $\mathrm{D}_{28 \mathrm{~K}}(\mathrm{CB} 38$; 
Swant, Switzerland) antibodies at $4^{\circ} \mathrm{C}$ overnight. Slices were then incubated with Alexa Fluor 488-conjugated AffiniPure Goat anti-rabbit IgG secondary antibody (111545-003; Jackson ImmunoResearch, USA) for 1.5 hours. For Thioflavin-S staining, slices were stained with $0.015 \%$ Thioflavin-S (T1892; Sigma, USA) for 15 minutes at room temperature. After mounting, slides were imaged using a Zeiss fluorescence microscope (Axio Observer A1; Zeiss, Germany).

\section{Cell culture}

SH-SY5Y human neuroblastoma cell line was maintained in Minimum Essential Medium (MEM, 41500-034; Gibco, USA) plus F-12 nutrient mixture (21700-075; Gibco, USA) supplemented with 10\% fetal bovine serum (FBS, SH3007; HyClone, USA), 0.11 $\mathrm{g} / \mathrm{L}$ sodium pyruvate, and $1.69 \mathrm{~g} / \mathrm{L}$ sodium bicarbonate. $\mathrm{BV}_{2}$ microglia cell line was maintained in Dulbecco's modified Eagle's medium (DMEM, 12100-046; Gibco, USA) supplemented with 10\% FBS, 1\% L-glutamine (GLL01; Caisson laboratory, USA), and $1.85 \mathrm{~g} / \mathrm{L}$ sodium bicarbonate. Cell lines were grown at $37^{\circ} \mathrm{C}$ in a humidified $5 \% \mathrm{CO}_{2}$ chamber.

\section{In vitro $\mathrm{A} \beta$ aggregation}

HFIP treated A $\beta$ (Ultra-pure A $\beta 42$, HFIP, A1163-2; Kelowna) was dissolved with DMSO, and the A $\beta$-DMSO solution was then added into $10 \mathrm{mM}$ Tris/PBS buffer to form $100 \mathrm{uM} \mathrm{A} \beta$ solution. The pallet was further removed from $\mathrm{A} \beta$ solution by centrifugation $(17000 \times \mathrm{g}, 15 \mathrm{~min}$, $\left.4^{\circ} \mathrm{C}\right)$. The supernatant of $100 \mu \mathrm{M} \mathrm{A} \beta$ solution was then kept at $4{ }^{\circ} \mathrm{C}$ for $24 \mathrm{~h}$ to form oligomer $\mathrm{A} \beta$. The oligomeric $\mathrm{A} \beta$ was characterized by using immunoblotting (Figure $11 \mathrm{~A}, \mathrm{CSP}=0 \mu \mathrm{M})$.

To determine whether CSP could alter A $\beta$ aggregation, $5 \mu \mathrm{M}$ HFIP-A $\beta$ was incubated with 0,22 , 44, 220, and $440 \mu \mathrm{M}$ CSP for 24 and 48 hours, and their aggregation status was determined by immunoblotting.

\section{Immunoblotting}

Cell lysates (10 $\mu \mathrm{g}$ of total protein) or aggregated A $\beta$ peptide were separated via $10 \%$ Tris-glycine polyacrylamide gel electrophoresis, transferred to polyvinylidene difluoride (PVDF, IPVH00010; Millipore, Germany) membranes. Membranes were blocked in casein blocking buffer (B6429; Sigma Aldrich, USA) for 1 hours and probed with primary antibody for anti-iNOS (610328; BD Bioscience, USA), anti-GAPDH (G8795; Sigma Aldrich, USA) or anti-A $\beta$ (6E10, SIG-39320; Covance, USA) antibodies. Membranes were washed with TBST buffer (150 mM NaCl, $10 \mathrm{Mm}$ Tris-HCl, and $0.05 \%$ Tween-20, $\mathrm{pH} 8.0$ ) and probed with horseradish peroxidase (HRP) conjugated goat anti-mouse IgG and goat anti-rabbit IgG (12-349, 12-348; Merck Millipore,
Germany). Protein signals were visualized using a chemiluminescent HRP substrate ECL detection system (WBKLS0500; Merck Millipore, Germany) and quantified by a luminescence imaging system (LAS-4000; Fujifilm, Japan).

\section{MTT assay}

SHSY-5Y cells reaching 75\% confluence were incubated with different concentrations of CSP or unnanosized curcuminoid for 4 hours at $37^{\circ} \mathrm{C}$, and then treated with $5 \mu \mathrm{M}$ oligomeric $\mathrm{A} \beta$ was added at a final concentration of $5 \mu \mathrm{M}$. After 48 hours incubation, medium were removed and $10 \mu \mathrm{L}$ of 3-(4, 5-Dimethylthiazol-2yl)-2, 5-diphenyltetrazolium bromide (MTT, $10 \mathrm{mg} / \mathrm{mL}$ ) solution were added for 4 hours incubation. Cells were then lysed with $100 \mu \mathrm{l}$ of lysis buffer (10\% SDS and 20 $\mathrm{mM} \mathrm{HCl}$ ) at $37^{\circ} \mathrm{C}$ overnight. Cell survival was determined according to the optical density at $570 \mathrm{~nm}$ with the ELISA reader (TECAN Sunrise ${ }^{\mathrm{TM}}$ Absorbance Reader, Switzerland).

\section{Phagocytosis assay}

$\mathrm{BV}_{2}$ microglial cells were seeded in 24-well plates at a density of approximately $8 \times 10^{4}$ cells in each well. $\mathrm{BV}_{2}$ cells were incubated in the presence or absence of $2.2 \mu \mathrm{M}$ CSP for 1 hour and then incubated with $0.001 \%$ fluorescent microspheres beads (F8821; Molecular Probes, USA) coated with fetal calf serum for 3 hours incubation at $37^{\circ} \mathrm{C}$. Cells were washed with PBS for 3 times and then stained with Iba1 antibody. The cells and beads were visualized using fluorescence microscopy. The average number of ingested beads per cells was determined as phagocytosis index.

For A $\beta$ clearance, BV2 microglia cells were seeded at a density of $2 \times 10^{5}$ cells/well on poly-D-lysine coated coverslips. Attached microglia were treated with $1 \mu \mathrm{M}$ oA $\beta$ with 0 or $2.2 \mu \mathrm{M}$ CSP for 24 hours. The levels of A $\beta$ remaining in the media were determined by $A \beta 42$ ELISA.

\section{Quantitative real-time PCR (Q-PCR)}

The RNA from oA $\beta$ and CSP treated microglia were purified using TRI reagent (T9424, Sigma, MO, USA), and then immediately reverse transcribed into cDNA by MMLV high-performance reverse transcriptase (RT80125K, Epicentre, WI, USA). The mRNA expression levels were analyzed by using primers mixed with SYBR Green PCR Master Mix (10476600, Roche, Penzberg, Germany). A StepOnePlus Real-Time PCR System (Applied Biosystem, ABI, MA, USA) was used to monitor the changes of fluorescence intensity from PCR products. GAPDH was used as internal control. Primer sequence are: IL-4 F: 5'GAC GCC ATG CAC GGA GAT3', R: 5'TCT CTG TGG TGT TCT TCG TTG CT3'; YM1 F: 5'TTC TGG TGA AGG AAA TGC GTAAA3', R: 5'GCA 
GCC TTG GAA TGT CTT TCT C3'; GAPDH F: 5'GCA TCC ACT GGT GCT GCC3'; R: 5'TCA TCA TAC TTG GCA GGT TTC3'. The data were analyzed using StepOne software version 2.0.

\section{Statistical analysis}

Statistical analyses were performed with GraphPad Prism (Version 5.0; GraphPad, USA). Differences among multiple means were assessed by one-way, twoway ANOVA, followed by Bonferroni's post-hoc test or Tukey's multiple comparison test. Differences between two means were assessed by paired or unpaired $t$ test. The threshold for significance was defined as $p<0.05$. All data are presented as mean \pm SEM.

\section{Author contributions}

YHT and YYL performed the AD-related experiment and wrote the manuscript. CLC, RYC, and CCW prepared CSP and performed bioavailability and biosafety tests. IHC and $\mathrm{KCW}$ designed the experiment and wrote the manuscript.

\section{ACKNOWLEDGMENTS AND FUNDING}

Behavioral studies were carried out at the Animal Behavioral Core at Brain Research Center, National Yang-Ming University. The technical services of confocal images were provided by Imaging Core Facility of Nanotechnology of the UST-NYMU.

This work was supported by Taiwan Ministry of Science and Technology grant (MOST-1052320-B-010-031), National Health Research Institutes (NHRI-EX106-10614NI), Cheng Hsin General Hospital (105F003C27), Yen Tjing Ling Medical Foundation (CI106-2), Ministry of Economic Affairs, ROC (103-EC17-A-03-04-0332), and Taiwan Ministry of Education Aim for Top University Grant.

\section{CONFLICTS OF INTEREST}

The authors declare no conflicts of interest.

\section{REFERENCES}

1. Mori H, Takio K, Ogawara M, Selkoe DJ. Mass spectrometry of purified amyloid beta protein in Alzheimer's disease. J Biol Chem. 1992; 267:17082-6.

2. Bitan G, Kirkitadze MD, Lomakin A, Vollers SS, Benedek GB, Teplow DB. Amyloid beta -protein (abeta) assembly: abeta 40 and abeta 42 oligomerize through distinct pathways. Proc Natl Acad Sci U S A. 2003; 100:330-5.

3. Querfurth HW, LaFerla FM. Alzheimer's disease. N Engl J Med. 2010; 362:329-44.
4. Mawuenyega KG, Sigurdson W, Ovod V, Munsell L, Kasten T, Morris JC, Yarasheski KE, Bateman RJ. Decreased clearance of CNS amyloid- $\beta$ in Alzheimer's disease. Science. 2010; 330:1774.

5. Becher B, Spath S, Goverman J. Cytokine networks in neuroinflammation. Nat Rev Immunol. 2017; 17:49-59.

6. Heneka MT, Carson MJ, Khoury JE, Landreth GE, Brosseron F, Feinstein DL, Jacobs AH, Wyss-Coray T, Vitorica J, Ransohoff RM, Herrup K, Frautschy SA, Finsen B, et al. Neuroinflammation in Alzheimer's disease. Lancet Neurol. 2015; 14:388-405.

7. Rodríguez-Arellano JJ, Parpura V, Zorec R, Verkhratsky A. Astrocytes in physiological aging and Alzheimer's disease. Neuroscience. 2016; 323:170-82.

8. Tang Y, Le W. Differential roles of M1 and M2 microglia in neurodegenerative diseases. Mol Neurobiol. 2016; 53:1181-94.

9. Prokop S, Miller KR, Heppner FL. Microglia actions in Alzheimer's disease. Acta Neuropathol. 2013; 126:461-77.

10. Heneka MT, Kummer MP, Stutz A, Delekate A, Schwartz S, Vieira-Saecker A, Griep A, Axt D, Remus A, Tzeng TC, Gelpi E, Halle A, Korte M, et al. NLRP3 is activated in Alzheimer's disease and contributes to pathology in APP/ PS1 mice. Nature. 2013; 493:674-8.

11. Cherry JD, Olschowka JA, O'Banion MK. Neuroinflammation and M2 microglia: the good, the bad, and the inflamed. J Neuroinflammation. 2014; 11:98.

12. Liu YL, Chen WT, Lin YY, Lu PH, Hsieh SL, Cheng IH. Amelioration of amyloid- $\beta$-induced deficits by DcR3 in an Alzheimer's disease model. Mol Neurodegener. 2017; $12: 30$.

13. Chandra V, Pandav R, Dodge HH, Johnston JM, Belle SH, DeKosky ST, Ganguli M. Incidence of Alzheimer's disease in a rural community in india: the indo-us study. Neurology. 2001; 57:985-9.

14. Vas CJ, Pinto C, Panikker D, Noronha S, Deshpande N, Kulkarni L, Sachdeva S. Prevalence of dementia in an urban indian population. Int Psychogeriatr. 2001; 13:439-50.

15. Lim GP, Chu T, Yang FS, Beech W, Frautschy SA, Cole GM. The curry spice curcumin reduces oxidative damage and amyloid pathology in an Alzheimer transgenic mouse. J Neurosci. 2001; 21:8370-7.

16. Yang F, Lim GP, Begum AN, Ubeda OJ, Simmons MR, Ambegaokar SS, Chen PP, Kayed R, Glabe CG, Frautschy SA, Cole GM. Curcumin inhibits formation of amyloid beta oligomers and fibrils, binds plaques, and reduces amyloid in vivo. J Biol Chem. 2005; 280:5892-901.

17. Frautschy SA, Cole GM. Why pleiotropic interventions are needed for Alzheimer's disease. Mol Neurobiol. 2010; 41:392-409.

18. Ringman JM, Frautschy SA, Teng E, Begum AN, Bardens J, Beigi M, Gylys KH, Badmaev V, Heath DD, Apostolova LG, Porter V, Vanek Z, Marshall GA, et al. Oral curcumin for Alzheimer's disease: tolerability and efficacy in a 
24-week randomized, double blind, placebo-controlled study. Alzheimers Res Ther. 2012; 4:43.

19. Anand P, Kunnumakkara AB, Newman RA, Aggarwal BB. Bioavailability of curcumin: problems and promises. Mol Pharm. 2007; 4:807-18.

20. Begum AN, Jones MR, Lim GP, Morihara T, Kim P, Heath DD, Rock CL, Pruitt MA, Yang F, Hudspeth $\mathrm{B}, \mathrm{Hu} \mathrm{S}$, Faull KF, Teter B, et al. Curcumin structurefunction, bioavailability, and efficacy in models of neuroinflammation and Alzheimer's disease. J Pharmacol Exp Ther. 2008; 326:196-208.

21. Dolai S, Shi W, Corbo C, Sun C, Averick S, Obeysekera D, Farid M, Alonso A, Banerjee P, Raja K. "Clicked" sugarcurcumin conjugate: modulator of amyloid-beta and tau peptide aggregation at ultralow concentrations. ACS Chem Neurosci. 2011; 2:694-9.

22. Mourtas S, Canovi M, Zona C, Aurilia D, Niarakis A, La Ferla B, Salmona M, Nicotra F, Gobbi M, Antimisiaris SG. Curcumin-decorated nanoliposomes with very high affinity for amyloid-beta1-42 peptide. Biomaterials. 2011; 32:1635-45.

23. Gao Y, Li Z, Sun M, Guo C, Yu A, Xi Y, Cui J, Lou H, Zhai G. Preparation and characterization of intravenously injectable curcumin nanosuspension. Drug Deliv. 2011; 18:131-42.

24. Prasad S, Tyagi AK, Aggarwal BB. Recent developments in delivery, bioavailability, absorption and metabolism of curcumin: the golden pigment from golden spice. Cancer Res Treat. 2014; 46:2-18.

25. Mucke L, Masliah E, Yu GQ, Mallory M, Rockenstein EM, Tatsuno G, Hu K, Kholodenko D, Johnson-Wood $\mathrm{K}$, McConlogue L. High-level neuronal expression of abeta 1-42 in wild-type human amyloid protein precursor transgenic mice: synaptotoxicity without plaque formation. J Neurosci. 2000; 20:4050-8.

26. Palop JJ, Jones B, Kekonius L, Chin J, Yu GQ, Raber J, Masliah E, Mucke L. Neuronal depletion of calciumdependent proteins in the dentate gyrus is tightly linked to Alzheimer's disease-related cognitive deficits. Proc Natl Acad Sci U S A. 2003; 100:9572-7.

27. Cheng IH, Scearce-Levie K, Legleiter J, Palop JJ, Gerstein H, Bien-Ly N, Puoliväli J, Lesné S, Ashe KH, Muchowski PJ, Mucke L. Accelerating amyloid-beta fibrillization reduces oligomer levels and functional deficits in Alzheimer disease mouse models. J Biol Chem. 2007; 282:23818-28.

28. Chang WH, Chen MC, Cheng IH. Antroquinonol lowers brain amyloid- $\beta$ levels and improves spatial learning and memory in a transgenic mouse model of Alzheimer's disease. Sci Rep. 2015; 5:15067.

29. Chin J, Palop JJ, Puolivali J, Massaro C, Bien-Ly N, Gerstein H, Scearce-Levie K, Masliah E, Mucke L. Fyn kinase induces synaptic and cognitive impairments in a transgenic mouse model of Alzheimer's disease. J Neurosci. 2005; 25:9694-703.
30. Wang Y, Yin H, Wang L, Shuboy A, Lou J, Han B, Zhang $\mathrm{X}$, Li J. Curcumin as a potential treatment for Alzheimer's disease: a study of the effects of curcumin on hippocampal expression of glial fibrillary acidic protein. Am J Chin Med. 2013; 41:59-70.

31. Kraft AD, Harry GJ. Features of microglia and neuroinflammation relevant to environmental exposure and neurotoxicity. Int J Environ Res Public Health. 2011; 8:2980-3018.

32. Hensley K, Maidt ML, Yu Z, Sang H, Markesbery WR, Floyd RA. Electrochemical analysis of protein nitrotyrosine and dityrosine in the Alzheimer brain indicates regionspecific accumulation. J Neurosci. 1998; 18:8126-32.

33. Lao CD, Ruffin MT 4th, Normolle D, Heath DD, Murray SI, Bailey JM, Boggs ME, Crowell J, Rock CL, Brenner DE. Dose escalation of a curcuminoid formulation. BMC Complement Altern Med. 2006; 6:10.

34. Cheng AL, Hsu CH, Lin JK, Hsu MM, Ho YF, Shen TS, Ko JY, Lin JT, Lin BR, Ming-Shiang W, Yu HS, Jee $\mathrm{SH}$, Chen GS, et al. Phase I clinical trial of curcumin, a chemopreventive agent, in patients with high-risk or premalignant lesions. Anticancer Res. 2001; 21:2895-900.

35. Mishra S, Palanivelu K. The effect of curcumin (turmeric) on Alzheimer's disease: an overview. Ann Indian Acad Neurol. 2008; 11:13-9.

36. Reagan-Shaw S, Nihal M, Ahmad N. Dose translation from animal to human studies revisited. FASEB J. 2008; 22:659-61.

37. Frautschy SA, Hu W, Kim P, Miller SA, Chu T, HarrisWhite ME, Cole GM. Phenolic anti-inflammatory antioxidant reversal of Abeta-induced cognitive deficits and neuropathology. Neurobiol Aging. 2001; 22:993-1005.

38. Zhang L, Fang Y, Xu Y, Lian Y, Xie N, Wu T, Zhang H, Sun L, Zhang R, Wang Z. Curcumin improves amyloid beta-peptide (1-42) induced spatial memory deficits through BDNF-ERK signaling pathway. PLoS One. 2015; 10:e0131525.

39. Dong S, Zeng Q, Mitchell ES, Xiu J, Duan Y, Li C, Tiwari JK, Hu Y, Cao X, Zhao Z. Curcumin enhances neurogenesis and cognition in aged rats: implications for transcriptional interactions related to growth and synaptic plasticity. PLoS One. 2012; 7:e31211.

40. Ma QL, Yang F, Rosario ER, Ubeda OJ, Beech W, Gant DJ, Chen PP, Hudspeth B, Chen C, Zhao Y, Vinters HV, Frautschy SA, Cole GM. Beta-amyloid oligomers induce phosphorylation of tau and inactivation of insulin receptor substrate via c-Jun N-terminal kinase signaling: suppression by omega-3 fatty acids and curcumin. J Neurosci. 2009; 29:9078-89.

41. Wang C, Zhang X, Teng Z, Zhang T, Li Y. Downregulation of PI3K/Akt/mTOR signaling pathway in curcumin-induced autophagy in APP/PS1 double transgenic mice. Eur J Pharmacol. 2014; 740:312-20. 
42. Huang N, Lu S, Liu XG, Zhu J, Wang YJ, Liu RT. PLGA nanoparticles modified with a BBB-penetrating peptide co-delivering $A \beta$ generation inhibitor and curcumin attenuate memory deficits and neuropathology in Alzheimer's disease mice. Oncotarget. 2017; 8:81001-13. https://doi.org/10.18632/oncotarget.20944.

43. Heppner FL, Ransohoff RM, Becher B. Immune attack: the role of inflammation in Alzheimer disease. Nat Rev Neurosci. 2015; 16:358-72.

44. Carson MJ, Thrash JC, Walter B. The cellular response in neuroinflammation: the role of leukocytes, microglia and astrocytes in neuronal death and survival. Clin Neurosci Res. 2006; 6:237-45.

45. Sofroniew MV. Molecular dissection of reactive astrogliosis and glial scar formation. Trends Neurosci. 2009; 32:638-47.

46. Simpson JE, Ince PG, Lace G, Forster G, Shaw PJ, Matthews F, Savva G, Brayne C, Wharton SB; MRC Cognitive Function and Ageing Neuropathology Study Group. Astrocyte phenotype in relation to Alzheimer-type pathology in the ageing brain. Neurobiol Aging. 2010; 31:578-90.

47. Fiala $M$, Lin J, Ringman J, Kermani-Arab V, Tsao G, Patel A, Lossinsky AS, Graves MC, Gustavson A, Sayre J, Sofroni E, Suarez T, Chiappelli F, Bernard G. Ineffective phagocytosis of amyloid-beta by macrophages of Alzheimer's disease patients. J Alzheimers Dis. 2005; 7:221-32; discussion 55-62.

48. Bard F, Cannon C, Barbour R, Burke RL, Games D, Grajeda H, Guido T, Hu K, Huang J, Johnson-Wood K, Khan K,
Kholodenko D, Lee M, et al. Peripherally administered antibodies against amyloid beta-peptide enter the central nervous system and reduce pathology in a mouse model of Alzheimer disease. Nat Med. 2000; 6:916-9.

49. Fiala M, Liu PT, Espinosa-Jeffrey A, Rosenthal MJ, Bernard G, Ringman JM, Sayre J, Zhang L, Zaghi J, Dejbakhsh S, Chiang B, Hui J, Mahanian M, et al. Innate immunity and transcription of MGAT-III and toll-like receptors in Alzheimer's disease patients are improved by bisdemethoxycurcumin. Proc Natl Acad Sci U S A. 2007; 104:12849-54.

50. Nagerl UV, Mody I, Jeub M, Lie AA, Elger CE, Beck H. Surviving granule cells of the sclerotic human hippocampus have reduced $\mathrm{Ca}(2+)$ influx because of a loss of calbindin$\mathrm{D}(28 \mathrm{k})$ in temporal lobe epilepsy. J Neurosci. 2000; 20:1831-6.

51. Kook SY, Jeong H, Kang MJ, Park R, Shin HJ, Han SH, Son SM, Song H, Baik SH, Moon M, Yi EC, Hwang D, MookJung I. Crucial role of calbindin-D28k in the pathogenesis of Alzheimer's disease mouse model. Cell Death Differ. 2014; 21:1575-87.

52. Molinari S, Battini R, Ferrari S, Pozzi L, Killcross AS, Robbins TW, Jouvenceau A, Billard JM, Dutar P, Lamour Y, Baker WA, Cox H, Emson PC. Deficits in memory and hippocampal long-term potentiation in mice with reduced calbindin D28K expression. Proc Natl Acad Sci U S A. 1996; 93:8028-33. 